\title{
Development of a Novel Electrochemical Monitoring Method of Enzymic Hydrolysis
}

\author{
Xingyue Wei ${ }^{*}$, Lin Zhuo \\ College of Environment and Rsources, Chongqing Technology and Business University, Chongqing \\ 400067, P.R. China \\ *E-mail: xingyuewei_cq@yeah.net
}

doi: $10.20964 / 2017.04 .12$

Received: 8 January 2017 / Accepted: 12 February 2017 / Published: 12 March 2017

\begin{abstract}
In this work, we assessed the electrochemical behaviour of the products of substrates of the enzyme label, alkaline phosphate, ordinarily adopted into the field of electrochemical immunosensors. Cyclic voltammetry $(\mathrm{CV})$ as well as amperometry of such resultants were respectively conducted at glassy carbon (GC) and gold (Au) electrodes. With mouse IgG to be a model, an ALP enzyme-magnified amperometric immunosensor with a sandwich shape came into being. Such immunosensor worked through the electropolymerization of $o$-aminobenzoic acid (o-ABA) polymer with conductivity on Au as well as GC electrodes' appearance. Then the anti-mouse IgG adhered to the electrode appearance by covalent bonding between IgG antibody and the carboxyl species from poly $(o-\mathrm{ABA})$. When 2phospho-l-ascorbic acid was adopted to be a substrate, the most optimized signal could be generated through the poly $(o-\mathrm{ABA}) / \mathrm{Au}$ immunosensor, indicating amperometric immunosensors with the basis of a conductive polymer electrode system were of great sensitivity to concentrations of the mouse IgG down to $1 \mathrm{ng} / \mathrm{mL}$.
\end{abstract}

Keywords: Electrochemistry; Enzymic hydrolysis; Immunosensor; Electrode; Mouse IgG

\section{FULL TEXT}

(C) 2017 The Authors. Published by ESG (www.electrochemsci.org). This article is an open access article distributed under the terms and conditions of the Creative Commons Attribution license (http://creativecommons.org/licenses/by/4.0/). 